\title{
Issues and Challenges in Cross-Border in Higher Education: The Sub-Saharan (SSA) Experience
}

\author{
Nkechi Okoli* \\ Educational Foundations, University of Port Harcourt, Port Harcourt, Nigeria \\ *Corresponding author: majesse4live@yahoo.com
}

Received December 25, 2013; Revised January 15, 2013; Accepted January 30, 2013

\begin{abstract}
This study focuses on the poor and deteriorating quality of education in the Third World countries in relation to Cross-border in higher education (CBHE), as a result of colonisation and globalisation. By whatever standards, be they macroeconomic or social variable, the situation has been precipitous retrogression. Debt servicing obligation is on the increase. The subject is approached by application of conceptual analysis of colonialism, human capital theories, globalisation, and internationalisation. The emerging issues of participation, mobility, the growth of private institutions, finance \& quality and consequent challenges in area of digital divide, etc on the region are historically analysed. Findings reveal that participation and mobility are lopsided, Africa's talented brains are selected; they leave and never come back. Private institutions are on the increase and exorbitant fees are charged. Inequalities loom, only the rich send their children to school. The paper recommends accommodation of countries not benefiting from CBHE.
\end{abstract}

Keywords: Cross-border in Higher Education (CBHE), Issues and Challenges, Colonialism, Globalisation, SubSaharan Africa

\section{Introduction}

The study points to the fact that despite the upsurge in Cross-border in higher education (CBHE), quality education has suffered in the Third World Countries especially in the sub-Saharan Africa from the colonial period and further deterioration since the 1980s, as a result of globalisation. "Whatever indicators we use, be they macroeconomics or social variable the situation in the region has been sometime precipitous retrogression... our balance payments deficits have accelerated while inflation, debt and debt servicing obligation have escalated" [15]. The $21^{\text {st }}$ century has witnessed rapid development in CBHE around the globe that higher education has become real part of globalisation process with Cross-border meeting the demand and supply. This is so because developing countries cannot meet the rising world demand for tertiary education. Students experience cultural enrichment by studying abroad, governments support mobility of both students and teachers in order to achieve mix of cultural, political, labour market and trade participation. Suppliers of education see foreign students as sources of revenue, there is the employment of teachers around the world to raise institutional quality and enrich students learning opportunities. These are aspect of internationalisation of education. Thus higher education can no longer be discussed in strictly national context but borders on internationalisation which is an embodiment of the whole operation of higher education. CBHE has experienced expansion in the Western countries of Europe (UK, Germany, France), North America (US), Australia,
Asia (Japan) which are also traditional resource countries. In the U.S. nearly every college and university employs some form of distance education to deliver higher education. Across the world more students choose to study abroad, enrolling in foreign educational programmes. Some enroll in institutions in their countries or use internet to take courses. Africa is marginalised from CBHE. The question is: Does African education have the necessary take-off that could make it viable? Is African education in practical terms part of the global outfit? To what extent have globalisation and internationalisation strengthened or weakened Africa chances in the CBHE exercise? What are the constraints and forces at work? The paper looks at these questions in relation to some of the issues being raised in this paper: participation, mobility, the growth of private universities, and quality.

\section{Issues}

\subsection{Conceptual Frame Work}

Despite the colonialism theory which propounded the paternalistic practice of government that exported civilisation, African education problem dates back to colonial period of $19^{\text {th }}$ century. It was pointed out that some economists regard the colonial system as an extra economic hegemonial relation designed exclusively for exploitation [8]. Thus many have recognised that colonisation has continuing impact on SSA experience of the global economy. The identification of present structures in African education as a fall out of subjugation, 
colonialism, oppression and exploitation are therefore unsuited for democratic and self determination. The resources of colonisation organised and controlled by the colonial structures were to channel profits to London [10]. Technologically, Africa's dilemma in terms of servile condescension to European ideas is a real manifest in stalemate of instability which may be located in the historical facts of slavery and colonialism.

Globalisation is the force behind the changes taking place in higher education across the globe. It has become the concept with which huge economic, political, cultural changes that characterise human society at the turn of the century is interpreted. Globalisation will be seen in our context as the flow of technology, economy, knowledge, people, values, ideas across borders. Although globalisation has made advancement in information communication technology (ICT), yet it has, in its attempt to make the whole world a global village, divided the world into the superrich and absolutely poor. Africa is the poorest of the poor. African education has suffered serious setback as a result of the forces of globalisation which builds on history of slavery, colonisation and exploitation. Globalisation has through trade liberalisation opened the way for African resources to be carted away without any returns. Today globalisation flows of people etc have taken away intellectuals and scientists who leave the continent and never come back. In the World Bank it was explained that in the $21^{\text {st }}$ century global market, the richer countries attract and retain the world's best brains through effective policies that stimulate research and development activities which increase direct investment [7]. Africa is marginalized and would be devoid of her talented brains.

Moreover, the theoretical concept for the adoption of education and development policies is known as the human capital theory. The human capital theory postulates that the most efficient path to the national development of any society lies in the improvement of its population [5] . It was opined that education is not to be viewed simply as a form of consumption but rather as a productive investment [18]. It was noted that education does not only improve the individual choices available to men, but that an educated population provides the type of work force necessary for industrial and economic growth. It was based on this theory that nations expended large sums of revenue in education. It was pointed out that the theory provided justification for large public expenditure on education both in developed and developing countries [6]. This theory is in line with the ideologies of democracy and liberal progression in most western societies. Economists agree that it is the human resource of a nation, not its capital nor its material resources that ultimately determine the character and pace of its economic development. It was noted that human resources constitute the ultimate basis of wealth of nations. Capital and natural resources are passive factors of production, human beings are the active agents who accumulate capital, exploit natural resources, build social economic and political organization and carry forward national development [17]. It was explained that the role of education in the growth and development process is to view human capital as a critical input for innovation, research and development activities [19]. Education is seen as an intentional effort to increase resources needed for creating new ideas, consequently any increase in education will accelerate technological programme. The implication of human capital theory is that quality education is necessary for the production of better skilled work force. The poor looked to the education of their children as a way out of poverty in Africa. But globalization drastically changed this. It has led to the reframing of policies and operation of higher education globally and has left Africa disadvantaged. Internationalisation has to do with the greater mobility of students, teachers, institutional and educational programmes across national borders as an aspect of wider development of educational policies and programme designed to introduce international, intercultural or worldwide dimension into the purpose, function and provision of higher education. Internationalisation is transforming the world of higher education, and globalisation is changing the world of internationalisation.

\subsection{Participation}

In educational sector learning networks are about people who link up to share knowledge with one another. Autonomous African universities had international linkages (a kind of CBHE) with the U.S. and U.K. in the 1970 s. It was pointed out that many international bodies (UNESCO, USAID, Rockefeller, Ford, and Carnegie) sponsored education projects all over Africa. There was interaction in various areas of academics - conferences, staff exchange programmes, fellowships etc. African participation increased with twenty-six other members; Botswana, Ghana, Kenya, Liberia, Malawi, Nigeria etc were involved. Globalisation shattered this sharing. Africa's participation at the global level was drastically curtailed. The developed countries and New Industrial countries (NICs) are the key players in CBHE. University of Phoenix (U.S.) has the largest private university operated by Appollo Group of companies with campuses in Puerto Rico, Netherlands, Mexico and Canada. Brazil, India and China are active players. Netherlands Business School (Universitieit Nyenrode) has recently opened campus in Nigeria and Harvard is developing branch campuses in Cyprus and United Arab Emirate. The University of Nottingham has campuses in Malaysia and China. Jinau University will be the first Chinese university to open outside China and will do that in Thailand. Laureate Education (Sylvan Learning Systems) has purchased whole or partial private higher education institute in Chile, Mexico, Panama and Costa Rica and owns universities in Spain, Switzerland and France. Dubai has developed Business and Technology Media Free Zone and to date London School of Economics, India Manipal Academy of Higher Education and Universities of Wollongong and Monash from Australia are key players. West Minister University (UK) is the foreign academic partner of University of Bahrain, Nigeria, Uzbekistan and Kazakhstan. South Africa hosts over 61,000 international students, ranking $11^{\text {th }}$ top host country.

SSA students go to developed countries for studies and to work and never come back. They pay exorbitant fees and only the children of the rich study abroad. Globalisation has created inequalities and inequities. Thus SSA has the lowest participation rate in education at all 
levels world-wide including CBHE. Mpinganjiran and Ruginbana (2009) noted that lack of adequate education opportunities in the home country and the appeal of better opportunities abroad are some of the factors that influence CBHE mobility and participation. Many in SSA would like to go to the university, only an insignificant few gain admission. The desire to have more candidates get into the universities in Nigeria led to the establishment of private universities. It is disheartening that 41 private universities could accommodate only 49,884, (4\%) of total student enrollment. Only $5 \%$ of university age cohort is qualified for admission despite establishment of private universities. It was noted that there are 92 accredited private universities in South Africa, 64 in Ethiopia, Kenya, Tanzania, and Uganda etc have private universities. Colonisation gave way to slavery and exploitation and from that period the stage was set for debt burden. It is glaring that globalisation has intensified debt burden. Structural Adjustment Programme (SAP) led to inadequate funding of higher education and many inadequacies cropped up. The region is marginalised from global economy and so cannot fully participate. Support for study abroad and capacity building failed in the 1980s. As a result, quality education suffered, and with globalisation further deterioration occurred. The economic restructuring has resulted in segmentation of society into protected and unprotected and excluded. Africa is unprotected and excluded. SSA is marginalized from CBHE. Students, academicians etc from the region flow to that CBHE is fulfilling the desire to promote mutual understanding between countries through migration of skilled workers, the need to build a more educated workforce, to improve the quality of higher education in countries where students come from where foreign providers operate and foreign programmes are delivered generally for emerging economies and also to boost economies and population gaining access to higher education, yet SSA neither participates nor benefits from all these.

\subsection{Mobility}

Mobility involves movement of people (students, professors, scholars, researchers, experts, consultants), programmes (courses, academic programmes and degrees) and providers (institutions, consortia and companies). The implementation of GATS by WTO in 1995 included education as one of the 12 service sectors and recognised as tradable service, has given boost to CBHE. The mobility of students, the visible form of CBHE is on the increase in many countries since it is a good source of getting future highly skilled workers in certain specialized areas. The US is the preferred destination for cross-border education and nearly three quarters of all cross-border students are hosted by 10 main countries of the Organisation for Economic Co-operation(OECD). It states that in 1980 student mobility world-wide was 1.1 million, the number increased slightly to 1.3 million in 1990 and that in 2009165 million students participated in CBHE. It showed that between 1991 and 2005, the number of students enrolled in institutions of higher education globally was more than doubled from 68-137.9 million students. Gross Enrollment Ratio (GER) increased from
13.8 to $24 \%$ in same period. GER varies between $5 \%$ in African region to $70 \%$ in North America and Western Europe[22]. Student mobility is attracting greater attention in SSA because of the challenges confronting the region regarding development of human capital. World Bank (2009) noted that UNESCO, European Union and African Union recognise that without a strong higher education system it is difficult or even impossible for any developing country in Africa to achieve sustainable development. World Bank (2010) noted that SSA faces the greatest challenges in the provision of higher education. Despite enrollment over the past 4 decades with average annual rate of $8.4 \%$ compared with $4.3 \%$ for the world, SSA is still lagging behind. Although there has been a significant increase from 0.2 million in 1970 to 4.8 million, and the projected 18.6 million by 2015 , it is reported that the GER in higher education is 6\%[12]. UNESCO (2010) reports that SSA lags behind the rest of the world where ratios range between $13 \%$ in South West Asia and $72 \%$ in North America and Western Europe. The ratio for most developing regions is between $20 \%$ and $40 \%$. It was noted that the gap between SSA and other regions of the world has widened in the last decade[16]. Many writers argue against international students mobility because it constitutes brain drain for the countries (SSA) sending. It was argued that brain drain is the greatest challenge to development and deprives the region of the critical human resource capacity[21]. Other countries with high capacity of participation are Botswana, Democratic Republic of Congo, Lesotho .Mauritius, Namibia, The Seychelles, and Swaziland.

It was showed that nearly $90 \%$ of Chinese and Indian doctorate students would like to stay in the US after their study [3]. Muyale- Manenji, F. (1994) noted that debt repayment pushed African governments to embark on drastic measures like retrenchment, or rationalisation of workers, other crucial aspects of life like education, health, social etc were neglected. The stage was set for flight of talents which has been described as one of the deadliest blows of globalisation on African higher education. Universities in these countries Nigeria, Uganda, Botswana and Malawi as well as in the Caribbean, Latin America, and Asia took the IMF and all face the same dilemma especially in the area of education. Tebje (2004) pointed out that within 20 years, 127,000 Africans migrated from the continent. International Organisation for Migration (IOM) pointed out that Africa has been losing 20,000 professionals yearly since the 1990 . Ethiopia lost $75 \%$ of her skilled work-force from 1980-1991. Economic Commission for Africa has it that over 300,000 professionals reside outside Africa. So SSA sustains in addition, huge loss of human capital as a result of globalisation flows and nobody migrates to the region. Education, the financial administrative capacity response to growing demand is often grossly inadequate. The inadequacy has made it difficult for SSA to participate in the global struggle.

\subsection{Digital Inequalities}

Integration of technologies into the curricula has had positive effects on participants in CBHE across the globe especially in the North. Digital inequalities are however 
glaring between the North and South. SSA is marginalized in the use of communication technologies. Allen and Seaman (2007) noted that 1 in 250 people have access to the internet in the region. Only $15 \%$ of SSA rural households have electricity and in urban areas, power is elliptic even in universities and Centres of Continuing Education. Aker and Mbiti (2010) noted that mobile telephone subscription rates are not marched by increased coverage, for instance, $60 \%$ of SSAs were covered by mobile signal in 2008. High cost makes it difficult for people to connect onto telephones. The implications of these for future are rather serious. Most students go to cybercafés for internet use and not all can afford the cost. Student living in rural areas travel to nearest urban centres and sometimes there will be power failure. Constant network failure is common place. There exists internal divide. Africa had the highest ratio of mobile to telephone subscribers of any world region and is the least wired region in the world. It was noted that the total number of subscribers of 221 million of which 198 million were cellular phone subscribers was recorded in 2006. Egypt had 11 times the fixed penetration lines of Nigeria, while SSA had an average tele-density of $1 \%$ with the exception of South Africa. North Africa (Egypt, Algeria, Mauritania, Morocco, and Tunisia) had a comparable average of $11 \%$. About three quarters of the continent's fixed lines were found in only 6 out of 55 countries of the continent. Moreover there has been delay in establishing the needed political and regulatory frame-work for utilizing new technologies (ADEA, 2003). Few African nations have developed ICT policies. There are ownership and access problems due to socio-economic contexts of many students and staff. The poor conditions seen here is an indication that the region is handicapped in relation to competition at global economic markets and in active participation in CBHE.

\subsection{Emergence of Private Higher Education Institutions}

Higher education systems in developed, developing and less developed nations are undergoing manifold types of changes that are often interrelated. Social demand for higher education remains very high, especially in developing nations and systems are expanding fast while the financial and administrative capacity response to growing demand for higher education is often inadequate. Given the insufficient and administrative capacity to respond to social demand for higher education, many countries globally committed to public system of education have adopted legislation that allows for development of a private higher education sector. This has led to tremendous growth in private provision of higher education over the last decade in developing countries. The forces of globalisation, it was noted that (GATS by WTO) have led to higher education being targeted by both public and private higher education institutions at both national and international market are treated as market goods and certain governments actively encourage their public higher education institutions to become active players in this area. U.S.A., Britain, Nigeria, Ghana, and South Africa all have private universities [11].

\subsection{Finance and Quality}

Adequate funding is a pathway to quality in higher education. The exponential growth in the mobility of stude nts, programmes and providers in CBHE offers new opportunities to increase access to higher education yet it also introduces a serious problem. One of the most important challenges in CBHE is how to ensure quality of academics and to achieve the recognition of legitimizing of what qualifications are awarded. Expansion raises the need for new initiatives to enhance quality provision in CBHE at the global level. Personnel and students are major actors in higher education. Quality demands that there is a vigorous policy in place for the development of staff. Clear policies should be established concerning higher education teachers who are exposed to latest updates in pedagogical skills through appropriate staff programme. Quality also requires that $\mathrm{CBHE}$ be characterised by its international expression of exchange of knowledge, interactive networking, mobility of teachers and students and international research projects. The curriculum, teaching and learning processes should be permeated by international dimension. All the attribute of quality discussed here can be attained through adequate funding and periodic accreditation of all aspect of higher education programme. .Unfortunately, higher education systems in the region suffer from poor quality due to inadequate funding, indeed the challenges of shrinking public funding for higher education and increase in enrollment have resulted among others in the erosion of quality education. Low levels in participation in CBHE and the poor quality of academic programmes hamper development of human resource and economic growth in the region.

The principle of international co-operation based on solidarity, recognition and mutual support, true partnership that equitably serves the intention of the partners and value of sharing knowledge and know-how across borders should govern relations among higher education institutions in both developed and developing countries and should benefit all the players.

Given the fact that inadequate funding is the malady afflicting higher education in SSA as a result of globalisation flows, the concept of globalisation as adopted in this study - the flow of technology, economy, knowledge, people, values, idea across borders, reveals that SSA is not in the picture at all; it becomes difficult to achieve the kind of exchange required in CBHE.

In all, the paper reveals, that globalisation has created inequalities and inequities between the North and South. While the north targets the goal of universalizing higher education, SSA concentrates effort on UPE. Only 5\% of university age cohorts enter university in SSA. Thus with expansion in the north and low enrollment in the south (SSA) inter regional disparity increased. It has led to the reframing of educational policies. Given the insufficient financial capacity to respond to social demands for higher education, many countries committed to public system of education now resort to adopting legislation that adopt private tertiary institutions. Participation and mobility in CBHE are only one sided. No students, teachers or researchers come to SSA. Africa's talented brains are selected; they leave and never come back. Only the rich 
can afford high school fees. The digital divide is so wide and facilities for ICT are none available so that it will take time for SSA to compete at the global labour market. Student enrollment in higher education doubled, GER increased.

\section{Challenges}

The challenges are enormous. The digital divide is so wide and facilities for ICT and steady power are nonavailable. A grossly inadequate funding is a serious malady. The challenge of producing the caliber of pupils that should be trained to participate in knowledge economy is most urgent. Lack of human resource is a very serious issue .The challenge of how to attract SSA talented brains (academicians, professionals) back home from across the globe is serious. The poverty situation that hinders quality education is evident. Increasing debt burden is sad and challenging. Poor curricula, difficult environment for teaching and learning and all that make it difficult to attract the rest of the world to SSA are challenges.

\section{Recommendations}

The north should have a rethinking on how to make room for the developing countries at the global labour markets. It should think of ways and means of bridging the gap. Africa should find ways to bring back her gifted brains that migrated to other lands.

\section{Conclusion}

Globalisation despite all its positive impact in the world has really produced serious inequalities. The lack of ICT, technological innovation, and electricity in most parts of SSA is a serious handicap. Africa's loss of her gifted brains has created a vacuum that needs to be filled.

\section{References}

[1] Aker, J. C. \& Mbiti, M. (2010). Mobile Phones and Economic Development in Africa. [Online] Available: http://www.sites.tufts.edu/jennjaker/file/2010/09/akermobileafrica. pdf

[2] Allen, I. E. \& Seaman, J. (2007). Online Nation: Five Years of Growth in Online Learning. Massachusetts: The Sloans Cosortium.

[3] Devesh, K. \& McHale, J. (2005). Give Us Your Best and Brightest. The Global Hunt for Talent and Its Impact on the Developing World. Washington DC: Center for Global Development.

[4] Fafunwa, A. B. (1991). A History of Education in Nigeria. Ibadan: NPS
[5] Fagerlind, A. \& Saha, I.J. (1989). Education and National Development: A Comparative Perspective. New Delhi: Pergamon Press.

[6] Fagerlind, A and Saga, I.J. (1997). Education and Developments. New Delhi: Reed Educational Professionals Publishing

[7] Glanz, J. (2001) Trolling for Brains in International Waters in World Bank (2002). Constructing Knowledge Societies: New Challenges for Tertiary Education. Washington D.C.: World Bank

[8] Gottheil, F. M. (1997). On an Economic Theory. [Online] Available:

http://www.jstor.org/discover/10.2307/422444443677uid=2129\&u id $=48$ sid $=211) 0082279$

[9] Human Development Report (1996). Rising Inequality and the Effects of Globalization in Khor (2000). Globalisation and the South: Some Critical Issues. Ibadan: Spectrum Books Ltd.

[10] Karky, Ramesh (2009). Globalisation and Least Developed States in Nweze, C.E. (2009). (ed.) Contemporary Issues on Public International and Comparative Law: Essays in Honour of Professor Christian Nwachukwu Okeke. Florida: Vandeplas Publishing

[11] Knight J. (2003). GATS, Trade and Higher Education: Perspective 2003. London: The Observatory on Borderless Higher Education.

[12] Macgregor, K. (2008). South Africa: Private University Status [Online] Available: http://www.worlduniverseviews

[13] Manganjira, M. \& Rugimbana, R. (2009). Understand International Student Mobility: What Motivates African Choices. [Online] Available:

http://www.duplication.net.au/ANZMACO9/PaperANZMAC2009 $-412 \mathrm{pdf}$

[14] Muyale-Manenji, F. (1994). The Effects of Globalisation on Culture in Africa in the Eyes of an African Woman. [Online] Available:

http://www.wcccoc.org /wcc/what/jpc/cfffglob.html

[15] Obanya, Pai (2004). The Dilemma of Education in Africa. Nigeria: Heinemann Educational Books

[16] Pillay (2008). Higher Education Funding Frameworks in SADC. in P. Kotecha (ed.) Towards a Common Future: Higher Education in the SADC Region. Research Findings from Four SARUA Studies (Study Series 2008), Johannesburg: SARUA.

[17] Psacharopoupulos \& Woodhall (1997) in Fagerlind, A. and Saga, I.J. (1997) Education and Developments New Delhi: Reed Educational Professionals Publishing Ltd

[18] Schultz, T. (1961). Human Needs to Approach in life in Fagerlind, A. \& Saha, I.J. (1989). Education and National Development: A Comparative Perspective New Delhi: Pergamon Press.

[19] Smith, Adams (1970). An Inquiry into the Nature and Cause of the Wealth of Nations, London: Dent \& Sons Everyman's Library.

[20] Tebeje A. Brain Drain and Capacity Building in Africa. International Development Research Council (IDRC), 2005. [Online] Available: http://www.idrc.ca/en/ev-71249-201-1 DO_TOPIC.html

[21] Teichier, U. \& Yagci, Y. (2009). Changing Challenges of Academic Work: Concepts and Observations in Meek, V. L., Teichier, U. \& Kearney (eds.) Higher Education Research and Innovation: Changing Dynamics Kassel, Germany: International Centre for Higher Education Research Kassel.

[22] UNESCO Institute of Statistics Information Bulletin (2009). In the Southern Africa Development Community [Online] Available: www.uis.unesco.org/education/Documentslib7-studentmobilityafrica-2012-v4-enpdf

[23] Wallerstein, I. (1974-1989). The Modern World System (3 volumes). New York: New York Academic Press.

[24] World Bank (2009). Accelerating Catch-up: Tertiary Education for Growth in SSA. Washington D.C.: World Bank. 